\title{
Dynamic Analysis of Secretagogue-induced Amylase Secretion from Rat Pancreatic Acini Studied by Perifusion System
}

\author{
Kouichiro Imamura, Hideyuki WaKasugi, \\ Hiroshi SHINOZaKi, and Hiroshi IBAYASHI \\ The Third Department of Internal Medicine, \\ Faculty of Medicine, Kyushu University, \\ Higashi-ku, Fukuoka, 812 Japan
}

\begin{abstract}
A perifusion system was applied for the study on stimulusenzyme secretion coupling in dispersed pancreatic acini. The system is highly simple, preserves the acini up to more than $3 \mathrm{hr}$, and makes feasible clear-cut examination on the time course of enzyme secretion caused by secretagogues.

Caerulein $\left(10^{-9} \mathrm{M}\right)$ and carbamylcholine $\left(10^{-5} \mathrm{M}\right)$ caused a biphasic amylase secretory pattern consisting of an initial burst secretion and a sustained one. Caerulein induced a persistent amylase release even after cessation of the stimulation, while carbamylcholine-stimulated amylase release returned to basal levels. Atropine inhibited completely carbamylcholine-stimulated amylase release and the successive stimulation by caerulein evoked the amylase secretion with a decreased initial burst secretion. In calcium free medium, caerulein and carbamylcholine induced only a slight secretion, particularly in the sustained secretion phase and a gradual increase occurred with the addition of calcium.
\end{abstract}

Key Words: pancreas, perifusion, amylase, caerulein, carbamylcholine.

Recently, dispersed pancreatic acini have been used to investigate the effect of secretagogues on pancreatic enzyme secretion (PEIKIN et al., 1978; WILLIAMS et al., 1978). In studies of static incubation, however, it was difficult to examine the time course of enzyme secretion in detail. In the present study, we applied the perifusion which had originally been used for pancreatic segments by BURR et al. (1970), and developed for isolated islets by LACY et al. (1972), to dispersed rat pancreatic acini to elucidate the kinetics of enzyme secretion enhanced by secretagogues.

Using the perifusion system, we examined minutely the time course of enzyme secretion from dispersed acini caused by cholecystokinin (CCK) analogue caerulein

Received for publication May 11, 1983

今村浩一郎, 若杉英之, 篠崎博嗣, 井林 博 
and cholinergic agonist carbamylcholine. Many investigators previously demonstrated the requirement of extracellular calcium for CCK or cholinergic agents-induced enzyme secretion (ARGENT et al., 1973; BENZ et al., 1972; CASE and Clausen, 1973; Heisler et al., 1972; Hokin, 1966; Kanno, 1972; KanNo and Nishimura, 1976; RobBerecht and Christophe, 1971). Some investigators proposed the hypothesis that the triggering of stimulation is independent of extracellular calcium but is dependent on calcium from intracellular stores (GARDNER et al., 1979; Petersen and Ueda, 1976; Scheele and Haymovits, 1979: Schulz et al., 1981). Thus, we examined the effect of removing extracellular calcium on enzyme secretion caused by caerulein and carbamylcholine in the perifusion study.

\section{MATERIALS AND METHODS}

Perifusion of pancreatic acini. Rat pancreatic acini were prepared by a modification of the method of AMSTERDAM and JAMIESON $(1972,1974)$. One male Wistar King albino rat (250 to $350 \mathrm{~g}$ ) was decapitated after an overnight fast. The pancreas was removed and trimmed of fat, lymphnodes, and mesentery. Five $\mathrm{ml}$ of the standard medium (composition described below) with digestive enzyme, 200 U/ml collagenase (Type IV, Millipore Corp., Freehold, N.J.) was injected into the gland using a 27 gauge needle. The standard medium contained 20 mM HEPES ( $N$-2-hydroxyethyl-piperazine- $N$ '-2-ethanesulfonic acid, Wako Pure

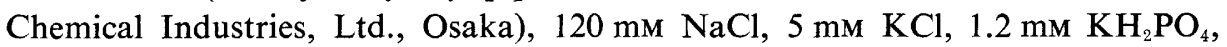
$2.5 \mathrm{mM} \mathrm{CaCl}_{2}, 1.2 \mathrm{mM} \mathrm{MgCl}_{2}, 5 \mathrm{mM}$ glucose, $0.2 \%$ bovine serum albumin (fraction V, Armour Pharmaceutical Co., Phoenix, Ariz.), 0.01\% soybean trypsin inhibitor (Type I-S, Sigma Chemical Co., Saint Louis, Mo.), and Eagles minimal essential amino acids and vitamins (Nissui Seiyaku Co., Ltd., Tokyo), adjusted to pH 7.4 and equilibrated with $100 \% \mathrm{O}_{2}$. After the first digestion at $37^{\circ} \mathrm{C}$ for $15 \mathrm{~min}$, the medium was discarded and the tissue was washed with the standard medium. The pancreas was incubated at $37^{\circ} \mathrm{C}$ with $5 \mathrm{ml}$ of digestion medium for another $40-45 \mathrm{~min}$ and washed 3 times with the standard medium. Pancreatic acini were liberated by sequential passage through 4 pipettes of different tip diameters $(3-1 \mathrm{~mm})$ in the standard medium containing $0.1 \%$ soybean trypsin inhibitor and filtered through one layer of gauze. The suspension of dispersed acini was laid over the standard medium containing $4 \%$ albumin and centrifuged for $3 \mathrm{~min}$ at $20 \mathrm{~g}$. The supernatant was discarded and the acini were resuspended in the standard medium, filtered again through one layer of gauze and washed twice with the medium. Finally the acini were suspended in $10 \mathrm{ml}$ of the standard medium.

Procedure for perifusion. The perifusion system was a modification of the method used for pancreatic segments by BURR et al. (1970) and pancreatic islets by LACY et al. (1972). As shown in Fig. 1, acini in a plastic chamber was perifused with a medium through tubing by a pump and perifusates were collected 


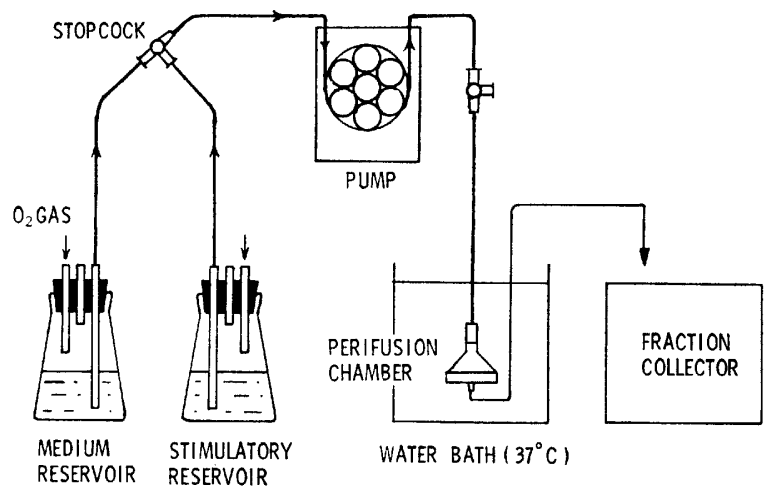

Fig. 1. Diagram of the perifusion system (see text for details).

using a fraction collector. Before the experiment, the system was filled and flowed with the standard medium for $30 \mathrm{~min}$. After isolation of pancreatic acini, a peristatic pump (SJ-1215, Mitsumi Scientific Industry, Tokyo) was stopped and a connector was removed from the chamber (plastic filter holder, Swinnex, Millipore Corp., Bedford Massachusetts) with a filter ( $5 \mu \mathrm{m}$ pore size, SMWP, Millipore Corp.). One $\mathrm{ml}$ of acini suspension was immediately injected with a plastic syringe into the chamber through the top and air was cleared; acini then settled on the filter. The syringe was removed and the connector was rapidly put into the chamber. The chamber was immersed and fixed in a water bath controlled at $37^{\circ} \mathrm{C}$ and the pump was started. The medium flowed at a rate of $0.6 \mathrm{ml} / \mathrm{min}$ through a silicon tubing of $1 \mathrm{~mm}$ diameter. The medium was changed one to another by switching the stopcock. Glass flasks were used for reservoirs and gassed with $100 \% \mathrm{O}_{2}$ throughout the experiment. Perifused medium was collected every min by the fraction collector (SF-100G, Tokyo, Kagaku Sangyo Co., Ltd., Tokyo) and stored for amylase assay.

Amylase activity was measured by the method of CESKA et al. (1969a, b) using Phadebas Amylase Test (Pharmacia Diagnostics, Piscataway, N.J.). To determine total amylase, $1 \mathrm{ml}$ of acini suspension, the same volume as that injected into the chamber, was sonicated and centrifuged at $1,500 \mathrm{~g}$ for $10 \mathrm{~min}$. Amylase release of each fraction was expressed as the percentage of the total amylase. Number of acinar cells that were perifused could not be counted, therefore we measured their protein content. To determine protein content, $1 \mathrm{ml}$ of acini suspension was washed 3 times with $2 \mathrm{ml}$ of saline and resuspended in $1 \mathrm{ml}$ of saline. The acini suspension was sonicated and centrifuged at $1,500 \mathrm{~g}$ for $10 \mathrm{~min}$. The protein concentration of the supernatant was measured by the method of LOWRY et al. (1951). The protein content of acini which were injected to the chamber was about $1 \mathrm{mg}$.

Carbamylcholine (carbachol) and atropine were obtained from Sigma Chemical Co., and caerulein was from Kyowa Hakko Kogyo Co., Tokyo. 


\section{RESULTS}

In the perifusion study, the rate of amylase release was relatively high at the beginning as a result of the pre-existing amylase extruded from the degraded acinar cells through isolation. As the rate became steady after the 90 min wash period, the acini were stimulated at 90 min from the start of the perifusion in each experiment. In this system, there was a dead space of $3 \mathrm{ml}$, which corresponded to 5 min, taking into account the flow rate.

\section{Caerulein-stimulated amylase release}

Acini were stimulated by caerulein at the concentration of $10^{-10} \mathrm{M}$, such being maximally effective in the static incubation (data not shown). The basal rate of amylase release was about $0.1 \%$ of the total amylase for $1 \mathrm{~min}$. The response was slow and reached a plateau in several minutes after the stimulation

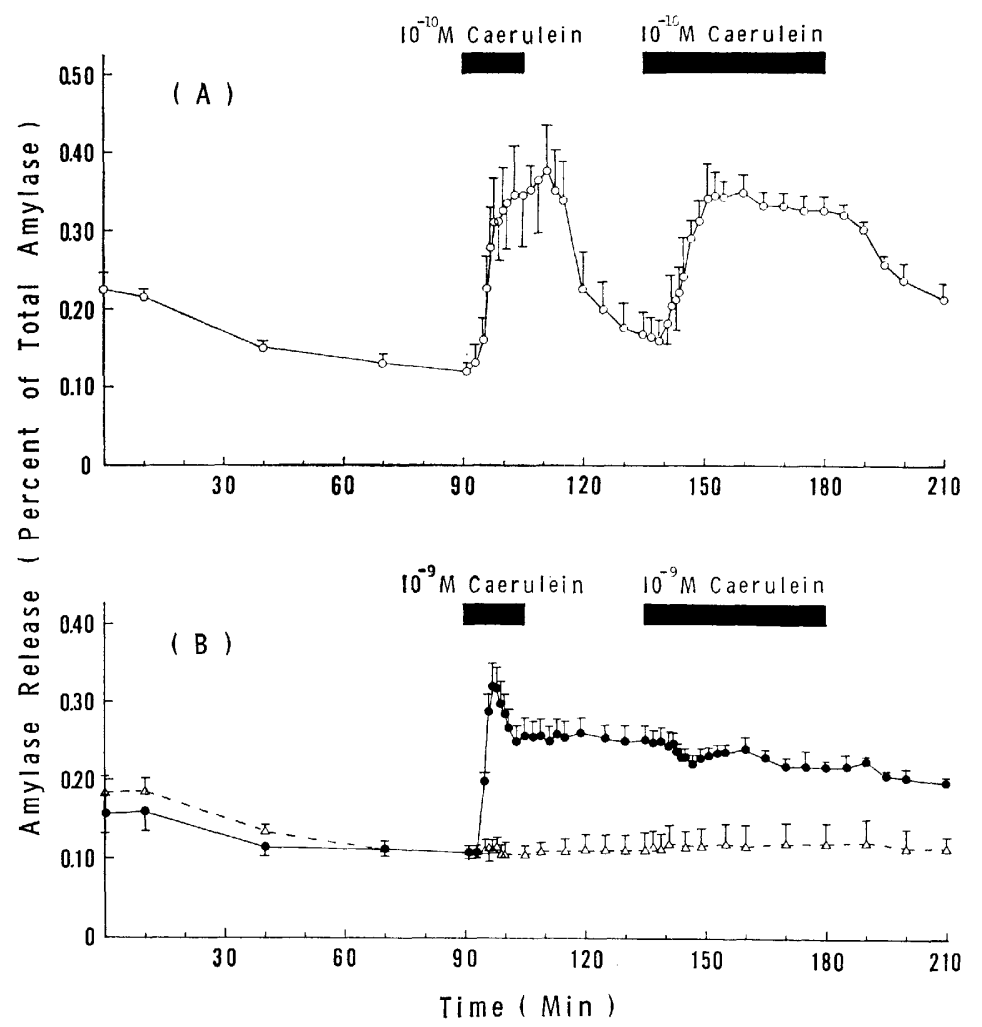

Fig. 2. Effect of caerulein on amylase release in perifusion of dispersed acini. Black bars indicate the period perifused with standard medium containing caerulein at a concentration of $10^{-10} \mathrm{M}(\mathrm{A}, \mathrm{O})$ and $10^{-9} \mathrm{M}(\mathrm{B}, \bullet)$. In experiments $\mathrm{B}$, acini were also perifused with standard medium (controls, $\triangle$ ). Amylase release for 1 min was expressed as the percentage of total amylase. Values are means from four experiments in A, seven in B, and four in controls. Vertical bars represent S.E. 
because of the dead space. When caerulein was withdrawn, the rate of amylase release decreased to near the basal level. Subsequent stimulation with $10^{-10}$ M caerulein produced again a slow release of amylase and after reaching a plateau there was a decline after cessation of the stimulation (Fig. 2A). When acini were stimulated by $10^{-9} \mathrm{M}$ caerulein, a biphasic secretory pattern was observed. It consisted of an initial burst secretion and a sustained secretion. The latter persisted even after cessation of the stimulation and subsequent stimulation with $10^{-9} \mathrm{M}$ caerulein induced no further increase of amylase release.

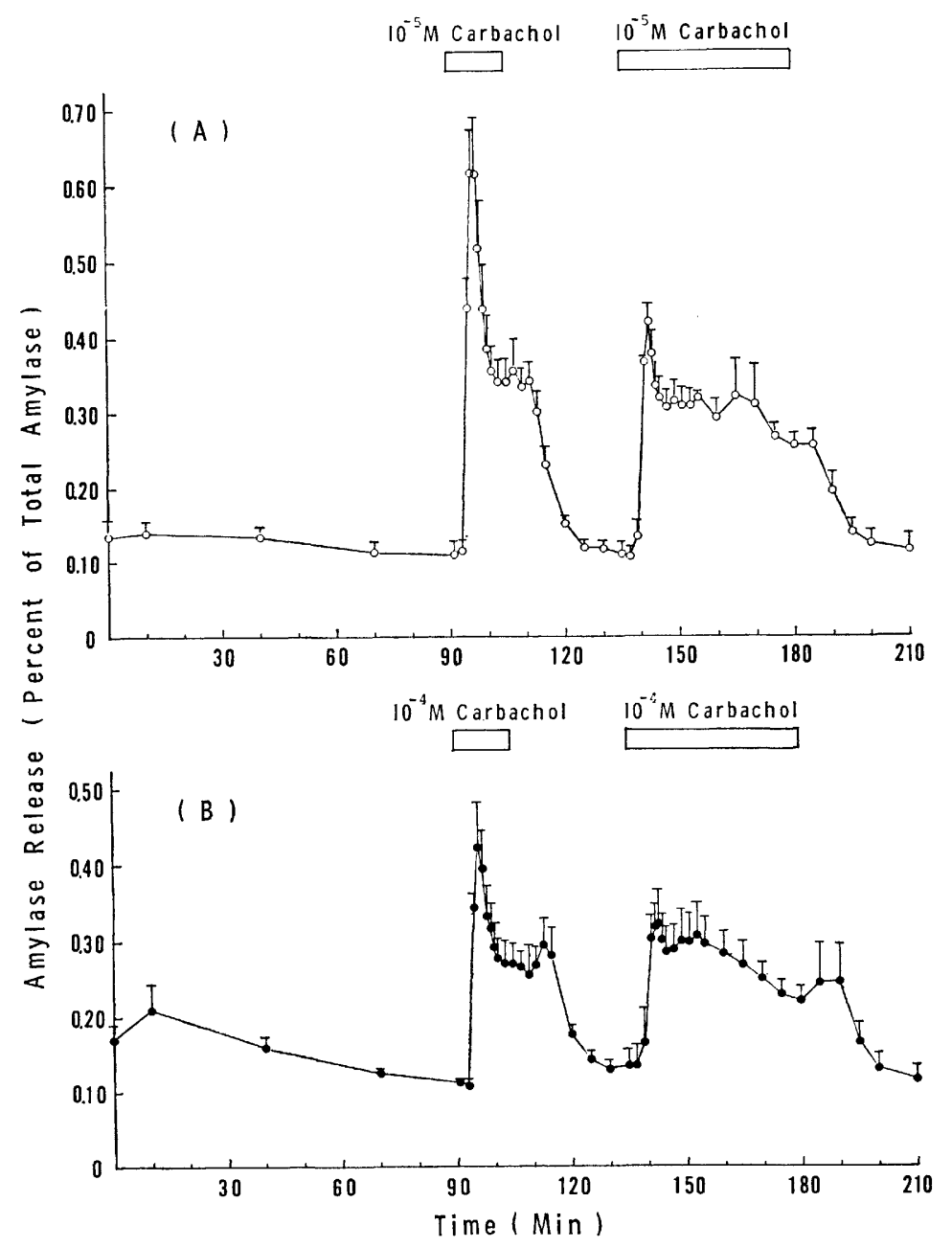

Fig. 3. Effect of carbamylcholine (carbachol) on amylase release in perifusion of dispersed acini. White bars indicate the period perifused with standard medium containing carbamylcholine at concentration of $10^{-5} \mathrm{M}(\mathrm{A}, \mathrm{O})$ and $10^{-4} \mathrm{M}(\mathrm{B}, \bullet)$. Values are means from four experiments. Vertical bars represent S.E.

Vol. 33, No. 5, 1983 
To exclude the possibility that the sustained amylase release was the result of degradation of the acinar cells, acini were simultaneously perifused with the standard medium containing no caerulein. There was no significant increase of amylase release up to $210 \mathrm{~min}$ (Fig. 2B).

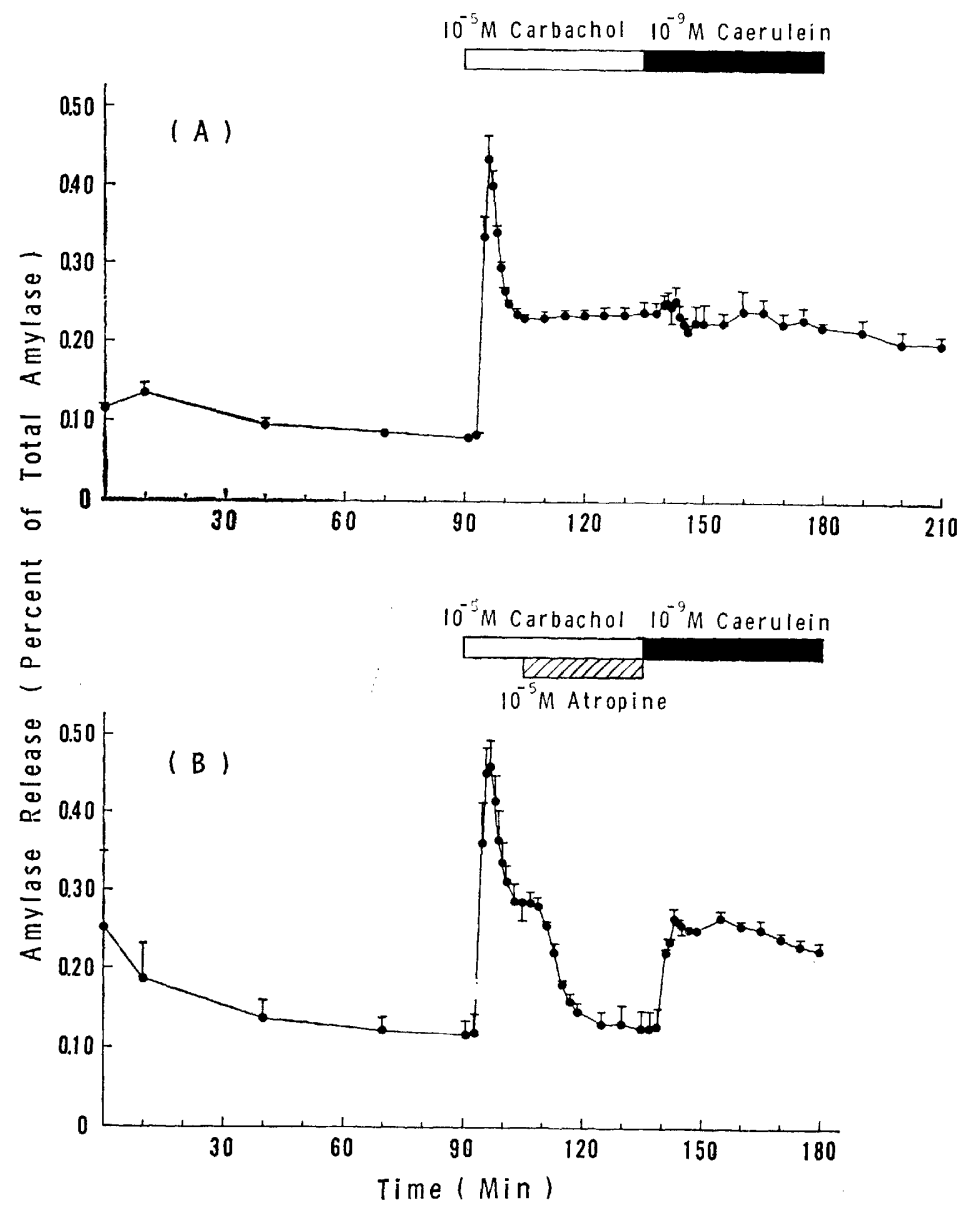

Fig. 4. (A) Effect of prior exposure to carbamylcholine (carbachol) on subsequent response of amylase release to caerulein in perifusion of dispersed acini. Acini were previously exposed to $10^{-5} \mathrm{M}$ carbamylcholine and subsequently perifused with standard medium containing $10^{-8} \mathrm{M}$ caerulein. Values are means from four experiments. Vertical bars represent S.E. (B) Effect of atropine on amylase release caused by carbamylcholine and subsequent response to caerulein in perifusion of dispersed acini. Acini were perifused with standard medium containing $10^{-5} \mathrm{M}$ carbamylcholine for $15 \mathrm{~min}$, then $10^{-5} \mathrm{M}$ atropine was added to the medium. After $30 \mathrm{~min}$, the medium was changed to standard medium containing $10^{-9} \mathrm{M}$ caerulein. Hatched bar indicates the period perifused with $10^{-5} \mathrm{M}$ atropine. Values are means from four experiments. Vertical bars represent S.E. 


\section{Carbamylcholine-stimulated amylase release}

Carbamylcholine caused a biphasic pattern of amylase release at the concentration of $10^{-5} \mathrm{M}$, such also being maximally effective in the static incubation (data not shown). The rate of amylase release rapidly increased to the maximum in several minutes and then decreased to a steady level. Withdrawal of stimulation resulted in a return of the amylase release to the basal rate. Subsequent stimulation with $10^{-5} \mathrm{M}$ carbamylcholine induced secretion but the magnitude of the second response was less in the initial burst secretion than that of the first one (Fig. 3A). When acini were stimulated with $10^{-4} \mathrm{M}$ carbamylcholine, a pattern similar to that seen with a dose of $10^{-5} \mathrm{M}$ soon became apparent and the residual stimulatory effect was not observed (Fig. 3B).

\section{Effect of atropine on amylase release}

The effect of a prior exposure to carbamylcholine on subsequent response to caerulein was examined. Prior stimulation with $10^{-5} \mathrm{M}$ carbamylcholine produced a biphasic pattern of amylase release and sustained constant for $45 \mathrm{~min}$. Successive stimulation with $10^{-9} \mathrm{M}$ caerulein maintained the rate of amylase release (Fig. 4A). When $10^{-5} \mathrm{M}$ atropine was added to the medium, the

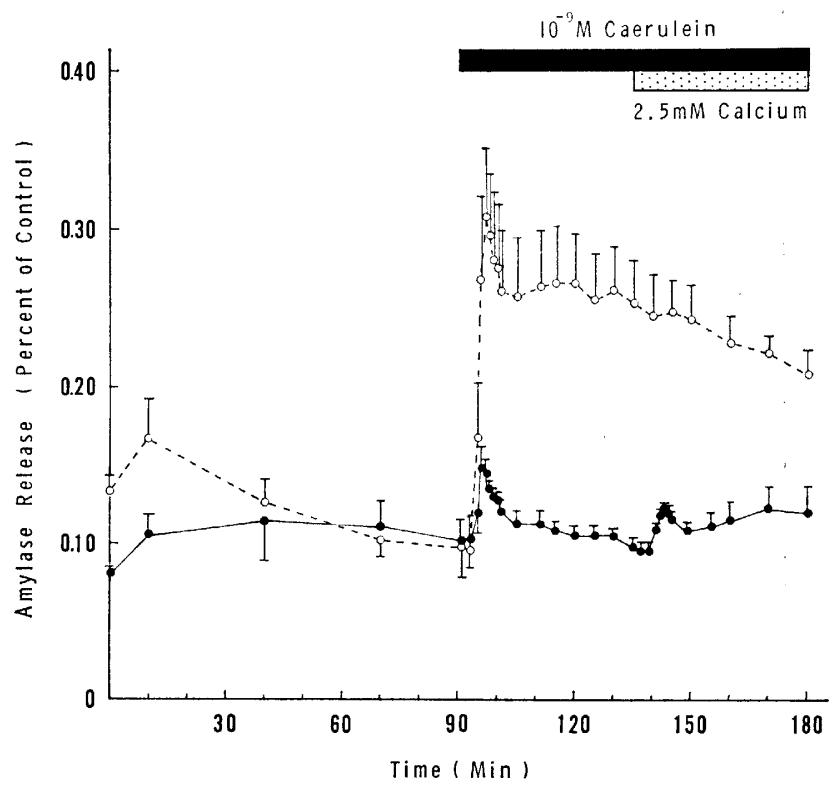

Fig. 5. Effect of removing extracellular calcium on caerulein induced amylase release in perifusion of dispersed acini. Acini were perifused with calcium free medium (๑) or standard medium containing $2.5 \mathrm{~mm}$ calcium $(O)$. Black bar indicates the period perifused with $10^{-8} \mathrm{M}$ caerulein. Dotted bar indicates the period perifused with $2.5 \mathrm{~mm}$ calcium in the experiment without calcium. Values are means from six experiments. Vertical bars represent S.E. 
carbamylcholine-induced amylase secretion was inhibited, and acini responded again to successive stimulation with $10^{-9} \mathrm{M}$ caerulein. However, the magnitude of the second response was less in the initial burst secretion (Fig. 4B).

\section{Effect of extracellular calcium on amylase release}

The removal of extracellular calcium did not alter the basal rate of amylase secretion. In a calcium free medium, however, $10^{-9} \mathrm{M}$ caerulein induced only a small amount of amylase secretion, and the peak was about $1 / 5$ that seen in the standard medium containing $2.5 \mathrm{~mm}$ calcium. In particular, the sustained amylase release was reduced in the calcium free medium. When the calcium concentration returned to $2.5 \mathrm{~mm}$, the secretory rate increased gradually, particularly in the sustained phase (Fig. 5). Secretory response of

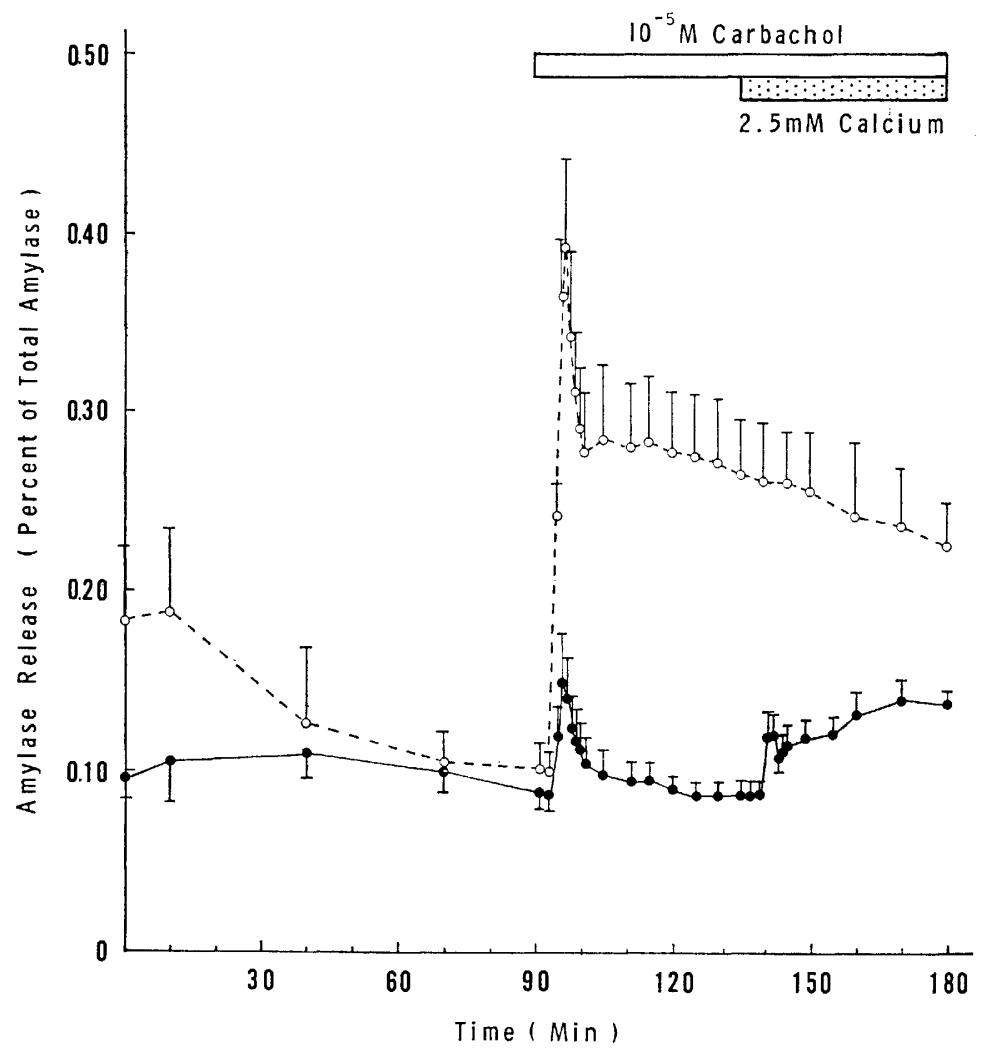

Fig. 6. Effect of removing extracellular calcium on carbamylcholine (carbachol)-induced amylase release in perifusion of dispersed acini. Acini were perifused with calcium free (O) or standard medium containing $2.5 \mathrm{~mm}$ calcium $(O)$. White bar indicates the period perifused with $10^{-5} \mathrm{M}$ carbamylcholine. Dotted bar indicates the period perifused with $2.5 \mathrm{~mm}$ calcium in the experiment without calcium. Values are means from six experiments. Vertical bars represent S.E. 
acini to $10^{-5} \mathrm{M}$ carbamylcholine in a calcium free medium was similar to that seen with caerulein, and was also increased gradually with the addition of calcium (Fig. 6).

\section{DISCUSSION}

In the present study, we modified the method of BURR et al. (1970) and LACY et al. (1972). GUDERLEY and HeISLER (1980) used a cell column suspension system in which dispersed rat pancreatic acinar cells were mixed with Biogel P-4 beads. FRANDSEN (1980) also described a perifusion system using a cell column in which isolated rat pancreatic acini were suspended with Biogel P-2. The Biogel served the dual purpose of retaining and separating the acini, thus preventing clogging during perifusion. The perifusion system we used did not require such cell columns and made feasible clear-cut examination of kinetics of minute enzyme release caused by secretagogues, in vitro. In control studies of perifusion, there was no significant increase of amylase release that would imply a degradation of acinar cells up to $210 \mathrm{~min}$. Cell viability was also confirmed as the acini responded well to the secretagogues and the enzyme secretion returned to the basal rate after cessation of stimulation (except for the case of $10^{-9} \mathrm{M}$ caerulein).

In the perifusion of acini, carbamylcholine caused a biphasic secretory pattern, that consisted of an initial burst secretion and a sustained secretion at maximal and supramaximal concentrations which had been determined in static incubation. Though the supramaximal concentration of caerulein also caused a biphasic secretory pattern, a monophasic pattern was observed with the maximal concentration. There is the possibility that the concentration of $10^{-10} \mathrm{M}$ of caerulein is actually submaximal. The biphasic secretory pattern of the pancreatic enzyme was also reported by other workers (FRANDSEN, 1980; GARDNER et al., 1979; Guderley and Heisler, 1980; KANNO and Nishimura, 1976; MatThews et al., 1973; Petersen and Ueda, 1976; Scheele and Haymovits, 1979; Schreurs et al., 1976; SCHULz et al., 1981).

In the present series, caerulein had different effects on amylase release, as compared with carbamylcholine. A ten times higher supramaximal concentration of caerulein induced a persistent amylase secretion even after cessation of stimulation. It seems unlikely that this effect was due to a relatively high concentration of caerulein, because residual stimulation was not observed with $10^{-4}$ M carbamylcholine, a dose which was equally ten times higher than its maximal concentration. A similar result was found with the octapeptide of CCK (CCK-OP) in a static incubation of dispersed pancreatic acini from guinea pig (Collins et al., 1981). In their studies, CCK-OP induced a persistent amylase release at relatively high concentrations, whereas carbamylcholine produced no residual stimulation. 
Desensitization is a phenomenon involving prior exposure to an agonist which reduces the subsequent response to the same agonist. This phenomenon was found in dispersed pancreatic acini from guinea pig by ABDELMOUMENE and GARDNER (1980). We also found that the second secretory response of acini to repeated stimulation with caerulein or carbamylcholine was less than the first. Interestingly, the initial burst secretion was reduced. A similar explanation may apply to the reduced response seen with caerulein after exposure to carbamylcholine, as these agents stimulate enzyme secretion through a common mechanism involving the same intracellular calcium pool. The caerulein-stimulated initial burst secretion was still reduced even when prior carbamylcholine-induced amylase release was inhibited by atropine, an antagonist of carbamylcholine.

The effect of omission of extracellular calcium on pancreatic enzyme secretion stimulated by CCK or cholinergic agents has been studied by many investigators. In a calcium free medium containing EGTA or EDTA, CCK or cholinergic agoniststimulated enzyme secretion was abolished in the isolated pancreas (ARGENT et al., 1973; KANNO, 1972), pancreatic slices (HoKIN, 1966) and fragments (BENZ et al., 1972; CASE and ClAUSEN, 1973), or decreased in pancreatic fragments (HeISLER et al., 1972; RoBBERECHT and CHRISTOPHE, 1971). Some investigators found that the initial secretion evoked by cholinergic agents of CCK was not affected yet the subsequent secretion was decreased or absent in the calcium free solution containing EGTA, in cases of the isolated pancreas (SCHREURS et al., 1976), pancreatic segments (Petersen and Ueda, 1976), lobules (Scheele and Haymovits, 1979), dispersed acinar cells (SCHULz et al., 1981), and acini (GARDNER et al., 1979). In the present study, the chelating agent was not added to the calcium free medium, but caerulein and carbamylcholine induced only a slight release of amylase and the sustained amylase release in particular was reduced in the calcium free medium. It is known that CCK and cholinergic agents increase calcium efflux in the absence of extracellular calcium (CASE and ClAuSEN, 1973; Christophe et al., 1976; SCHREURS et al., 1976; Williams and CHANDLER, 1975) and this calcium is thought to be released from intracellular stores (GARDNER, 1979; Williams, 1980). Thus, the stimulated enzyme secretion is probably triggered by the efflux of intracellular calcium followed by calcium re-uptake and the sustained secretion requires an influx of extracellular calcium into the cells occurred probably by an increased plasma membrane permeability to calcium (Kondo and Schulz, 1976; Schulz and StOlze, 1980). Namely, the initial burst secretion observed in our perifusion study corresponds to calcium efflux due to calcium release from an intracellular calcium trigger pool and the sustained enzyme secretion corresponds to an increased calcium influx into the cells. In this study, the basal rate of amylase release was not influenced by removal of the extracellular calcium in agreement with findings of other workers (BENZ et al., 1972; GARDNER et al., 1979; ScHREURs et al., 1976; Schulz et al., 1981; Williams et al., 1976). Some investigators did find a reduction in basal enzyme secretion in the absence of extracellular calcium (ARGENT 
et al., 1973; Case and Clausen, 1973; Heisler et al., 1972; Robberecht and Christophe, 1971; Williams and Chandler, 1975).

We thank M. Ohara for comments on the manuscript. This work was supported in part by a Grant-in-Aid for Scientific Research from the Ministry of Education, Science and Culture of Japan (Grant No. 244038) and a Research Grant from the Intractable Diseases Division, Public Health Bureau, Ministry of Health and Welfare, Japan.

\section{REFERENCES}

Abdelmoumene, S. and Gardner, J. D. (1980) Cholecystokinin-induced desensitization of enzyme secretion in dispersed acini from guinea pig pancreas. Am. J. Physiol., 239: G272G279.

Amsterdam, A. and JAMieson, J. D. (1972) Structural and functional characterization of isolated pancreatic exocrine cells. Proc. Natl. Acad. Sci. U.S.A., 69: 3028-3032.

Amsterdam, A. and Jamieson, J. D. (1974) Studies on dispersed pancreatic exocrine cells. I. Dissociation technique and morphologic characteristics of separated cells. J. Cell Biol., 63: 1037-1056.

Argent, B. E., Case, R. M., and Scratchered, T. (1973) Amylase secretion by the perfused cat pancreas in relation to the secretion of calcium and other electrolytes and as influenced by the external ionic environment. J. Physiol. (Lond.), 230: 575-593.

Benz, L., Ecrstein, B., Matthews, E. K., and Williams, J. A. (1972) Control of pancreatic amylase release in vitro: Effects of ions, cyclic AMP and colchicine. $B r . J$. Pharmacol., 44: 66-77.

Burr, I. M., Balant, L., Stauffacher, W., and Renold, A. E. (1970) Perifusion of rat pancreatic tissue in vitro: Substrate modification of theophylline-induced biphasic insulin release. J. Clin. Invest., 49: 2097-2105.

Case, R. M. and Clausen, T. (1973) The relationship between calcium exchange and enzyme secretion in the isolated rat pancreas. J. Physiol. (Lond.), 235: 75-102.

Ceska, M., Briath, K., and Brown, B. A. (1969a) A new rapid method for the clinical determination of alpha-amylase activities in human serum and urine. Optimal conditions. Clin. Chim. Acta, 26: 437-444.

CESKA, M., Brown, B., and Briath, K. (1969b) Ranges of alpha-amylase activities in human serum and urine and correlations with some other alpha-amylase methods. Clin. Chim. Acta, 26: 445-453.

Christophe, J. P., Frandsen, E. K., Conlon, T. P., Krishna, G., and Gardner, J. D. (1976) Action of cholecystokinin, cholinergic agents, and A-23187 on accumulation of guanosine 3',5'-monophosphate in dispersed guinea pig pancreatic acinar cells. J. Biol. Chem., 251: $4640-4645$.

Collins, S. M., Abdelmoumene, S., Jensen, R. T., and Gardner, J. D. (1981) Cholecystokinininduced persistent stimulation of enzyme secretion from pancreatic acini. Am. J. Physiol., 240: G459-G465.

FrandSEN, E. K. (1980) Amylase release from perifused immobilized acini from rat pancreas. In: Biology of Normal and Cancerous Exocrine Pancreatic Cells, ed. by Ribet, A., PradaYROL, L., and SucrNI, C. Elsevier/North-Holland Biochemical Press, Amsterdam, pp. 27-37.

GARDNER, J. D. (1979) Regulation of pancreatic exocrine function in vitro: Initial steps in the actions of secretagogues. Annu. Rev. Physiol., 41: 55-66.

Gardner, J. D., Costenbader, C. L., and Uhlemann, E. R. (1979) Effect of extracellular calcium on amylase release from dispersed pancreatic acini. Am. J. Physiol., 236: E745-

Vol. 33, No. 5, 1983 
E762.

Guderley, H. and Heisler, S. (1980) A model system for the study of stimulus-enzyme secretion coupling in rat pancreatic acinar cells. Can. J. Physiol. Pharmacol., 58: 965-973.

Heisler, S., FAST, D., and Tenenhouse, A. (1972) A role of $\mathrm{Ca}^{++}$and cyclic AMP in protein secretion from rat exocrine pancreas. Biochim. Biophys. Acta, 279: 561-572.

HokIN, L. E. (1966) Effects of calcium omission on acetylcholine-stimulated amylase secretion and phospholipid synthesis in pigeon pancreas slices. Biochim. Biophys. Acta, 115: 219-221.

KanNo, T. (1972) Calcium-dependent amylase release and electrophysiological measurement in cells of the pancreas. J. Physiol. (Lond.), 226: 353-371.

KANNO, T. and NishimurA, O. (1976) Stimulus-secretion coupling in pancreatic acinar cells: Inhibitory effects of calcium removal and manganese addition on pancreozymin-induced amylase release. J. Physiol. (Lond.), 257: 309-324.

Kondo, S. and Schulz, I. (1976) $\mathrm{Ca}^{++}$fluxes in isolated cells of rat pancreas. Effects of secretagogues and different $\mathrm{Ca}^{++}$concentrations. J. Membr. Biol., 29: 185-203.

LaCy, P. E., WAlker, M. M., and Fink, C. J. (1972) Perifusion of isolated rat islets in vitro: Participation of the microtubular system in the biphasic release of insulin. Diabetes, 21 : 987-998.

Lowry, O. H., Rosebrough, N. J., Farr, A. L., and Randall, R. J. (1951) Protein measurement with Folin phenol reagent. J. Biol. Chem., 193: 265-275.

Matthews, E. K., Petersen, O. H., and Williams, J. A. (1973) Pancreatic acinar cells: Acetylcholine-induced membrane depolarization, calcium efflux and amylase release. J. Physiol. (Lond.), 234: 689-701.

Peikin, S. R., Rottman, A. J., Batzri, S., and Gardner, J. D. (1978) Kinetics of amylase release by dispersed acini prepared from guinea pig pancreas. Am. J. Physiol., 235: E743E749.

Petersen, O. H. and Ueda, N. (1976) Pancreatic acinar cells: Role of calcium in stimulussecretion coupling. J. Physiol. (Lond.), 254: 583-606.

Robberecht, P. and Christophe, J. (1971) Secretion of hydrolases by perfused fragments of rat pancreas: Effects of calcium. Am. J. Physiol., 220: 911-917.

Scheele, G. and Haymovits, A. (1979) Cholinergic and peptide-stimulated discharge of secretory protein in guinea pig pancreatic lobules. J. Biol. Chem., 254: 10346-10353.

Schreurs, V. V. A. M., Swarts, H. G. P., Depont, J. J. H. H. M., and Bonting, S. L. (1976) Role of calcium in exocrine pancreatic secretion. II. Comparison of the effects of carbachol and the ionophore A-23187 on enzyme secretion and calcium movements in rabbit pancreas. Biochim. Biophys. Acta, 419: 320-330.

Schulz, I. and Stolze, H. (1980) The exocrine pancreas: The role of secretagogues, cyclic nucleotides, and calcium in enzyme secretion. Annu. Rev. Physiol., 42: 127-156.

Schulz, I., Wakasugi, H., Stolze, H., Kribben, A., and HaAse, W. (1981) Analysis of Ca ${ }^{2+}$ fluxes and their relation to enzyme secretion in dispersed pancreatic acinar cells. Fed. Proc., 40: 2503-2510.

Williams, J. A. (1980) Regulation of pancreatic acinar cell functions by intracellular calcium. Am. J. Physiol., 238 : G269-G279.

Williams, J. A., Carry, P., and Moffat, B. (1976) Effects of ions on amylase release by dissociated pancreatic acinar cells. Am. J. Physiol., 231 : 1562-1567.

Williams, J. A. and Chandler, D. (1975) $\mathrm{Ca}^{++}$and pancreatic amylase release. Am. J. Physiol., 228: 1729-1732.

Williams, J. A., Korc, M., and Dormer, R. L. (1978) Action of secretagogues on a new preparation of functionally intact, isolated pancreatic acini. Am. J. Physiol., 235: E517-E524. 